ZOOLOGIA 27 (2): 309-312, April, 2010

doi: $10.1590 /$ S1984-46702010000200016

\title{
A dwarfish new species of Phylloicus (Trichoptera: Calamoceratidae) from Southeastern Brazil
}

\author{
Leandro L. Dumas ${ }^{1,2} \&$ Jorge L. Nessimian ${ }^{1,3}$ \\ 'Departamento de Zoologia, Instituto de Biologia, Universidade Federal do Rio de Janeiro. Caixa Postal 68044, Cidade \\ Universitária, 21944-970 Rio de Janeiro, Rio de Janeiro, Brazil.E-mail: dumas_bioufrj@yahoo.com.br; nessimia@acd.ufrj.br
}

\begin{abstract}
Phylloicus monneorum sp. nov. is described and illustrated based on specimens collected in the Mantiqueira mountain range, Itatiaia, state of Rio de Janeiro, Brazil. The new species is the smallest within the genus. The male can be distinguished by the preanal appendages short, wide, flattened and with irregular margins, and by the deeply $\mathrm{V}$ shaped tergum $X$. The female is also described and figured. The immature stages are unknown.
\end{abstract}

KEY WORDS. Atlantic Forest; female description; Neotropical Region; Phylloicus monneorum sp. nov.

Calamoceratidae is a small caddisfly family with eight extant genera comprising about 175 described species worldwide (Holzenthal et al. 2007). Only two endemic genera occur in the Neotropics and both were recently revised by Prather (2003, 2004). Banyallarga Navás, 1916 has 18 described species from Central America to northwestern South America, without records from Brazil (Prather 2004). Phylloicus Müller, 1880 has 55 known species from southwestern United States to throughout South America, including the Antilles. The genus is especially diverse in Brazil, Peru, and Venezuela (Prather 2003). Up till now 19 species were known from Brazil, with eight of them endemic to the country (Prather 2003, PAProcki et al. 2004).

Adults of many Phylloicus species are brigthly or strikingly colored, with diagnostic patterns of forewing spots formed by an iridescent membrane or colourfull setae (Prather 2003). Many species are more diurnal in their activity than most caddisflies and are less frequently attracted to light traps (FunT et al. 1999). The immature stages are usually found in slower, depositional areas of small streams and rivers where they feed as shredders of leaf litter (Holzenthal et al. 2007). Besides, the larva of $P$. bromeliarum Müller, 1880 is unique for dwelling in bromeliad tanks (MülLER 1880). Larvae build distinctive flattened cases made of large pieces of excised leaves (Prather 2003).

A new species of Phylloicus was collected in Itatiaia, Mantiqueira mountain range, state of Rio de Janeiro. Herein, we describe and figure this species, including the female. The immature stages are unknown.

\section{MATERIAL AND METHODS}

The specimens were collected in activity with entomological nets during the day and conserved in $80 \%$ ethanol. In order to observe the genital structures, the abdomen was removed and cleared in $10 \% \mathrm{KOH}$. The illustrations were made under a stereomicroscope and a microscope, both equipped with a camera lucida. The terminology used in the descriptions follows that of Prather (2003). The type specimens are deposited in the Coleção Entomológica Professor José Alfredo Pinheiro Dutra, Departamento de Zoologia, Universidade Federal do Rio de Janeiro (DZRJ), state of Rio de Janeiro, and in the Museu de Zoologia, Universidade de São Paulo (MZSP), state of São Paulo, both in Brazil.

\section{TAXONOMY}

\section{Phylloicus monneorum sp. nov.}

Figs 1-9

Description. Adult (Figs 1-9): forewing length: 6.5-7.2 mm $(\mathrm{n}=6)$. Head and maxilary palps dark brown. Antennae chestnut brown; scapes dark brown. Labial palps stramineous. Dorsum of thorax bright dark brown; ventrally pale brown. Legs pale tan. Wings golden brown, without spots, in alcohol. Abdomen pale yellowish-brown. Head: ocelli absent. Antennae about twice forewing length; scape broad, bearing dark setae. Central setal area not evident. Anterior setal wart small, with few stout setae; anteromesal setal warts single, rounded; posterior setal warts long oval; posterolateral setal warts large, behind eyes. Posteromesal ridge short, at posterodorsal margin of head. Maxillary palps 5-segmented, long, with golden dark setae. Labial palps 3-segmented, short. Thorax (Figs 1-2): pronotum short, with two pairs setal warts, one mesal and one lateral. Mesoscutum with setal warts arranged in two sublateral longitudinal bands of setal punctures; mesoscutellum quadrangular, without setal punctures. Metascutellum triangular. Metathoracic legs with posterior fringe of long, dark setae. Tibial spur formula 2,4,4. Forewings flat, with venation typical for the genus; forks I-V present in male; discoidal cell half lenght of thyridial cell; median cell closed (Fig. 1). Hindwings broad, with basal brush present; forks II, III and V present; with open discoidal and median cells (Fig. 2). 
Male (Figs 3-6): preterminalic abdominal terga without anteromesal notch. Terga III-V unmodified, without membranous lobes or sclerotized processes. Corematic structures absent. Sternum VII with short, acute anteromesal process. Sternum VIII similar to VII, with smaller process. Tergum IX with mesal ridge extending half-lenght of segment; posterior margin slightly projected, obtuse at apex; posteromesal surface covered with fine pilosity; lateral margin with roll of approximately 15 long dark setae; lateral ridge present (Fig. 4); sternum IX not elongate, narrower mesally than laterally, with internal ridges mesolaterally (Fig. 5). Preanal appendages shorter than tergum $X$, subtriangular, flattened; lateral margins irregular (indented), bearing dark, long setae (Fig. 3). Tergum X without basolateral and basodorsal processes; apex rounded, in lateral view (Fig. 3); deeply notched, V-shaped; covered with short setae, in dorsal view (Fig. 4). Inferior appendages long, 2-segmented (Fig. 3); coxopodite (first segment) relatively long, cylindrical, bearing long, stout setae (Figs 3 and 5); harpago (sec- ond segment) short, cylindrical, with short, fine setae; short, pointed, peglike setae on apex (Figs 3 and 5). Phallic apparatus simple, tubular, slightly curved at base; phallotremal sclerite of average size, longest dimension less than diameter of phallobase (Fig. 6); wider at base, sharply tapered, in lateral view (Fig. 6); horseshoe-shaped, in ventral view (Fig. 5).

Female (Figs 7-9): Sternum VII without anteromesal process. Tergum VIII without posterolateral brush; sternum VIII cleft posteromesally to anterior ridge, bearing short marginal setae (Fig. 9). Tergum IX with mesal ridge (Fig. 8); anterior and posterior lobes of sternum IX sclerotized and striate; anterior lobe less sclerotized than posterior lobe (Fig. 7). Tergum X appendages shorter than tergum, base indistinct, with long setae; apex of tergum X obtuse (Fig. 8); digitate lateral process absent (or not evident). Sternum $\mathrm{X}$ with short fine setae posterolaterally to anal opening (Fig. 7). Vaginal apparatus anterior and posterior sclerites subequal in lenght; anterior sclerite rounded apically, with basolateral pointed projections; pos-
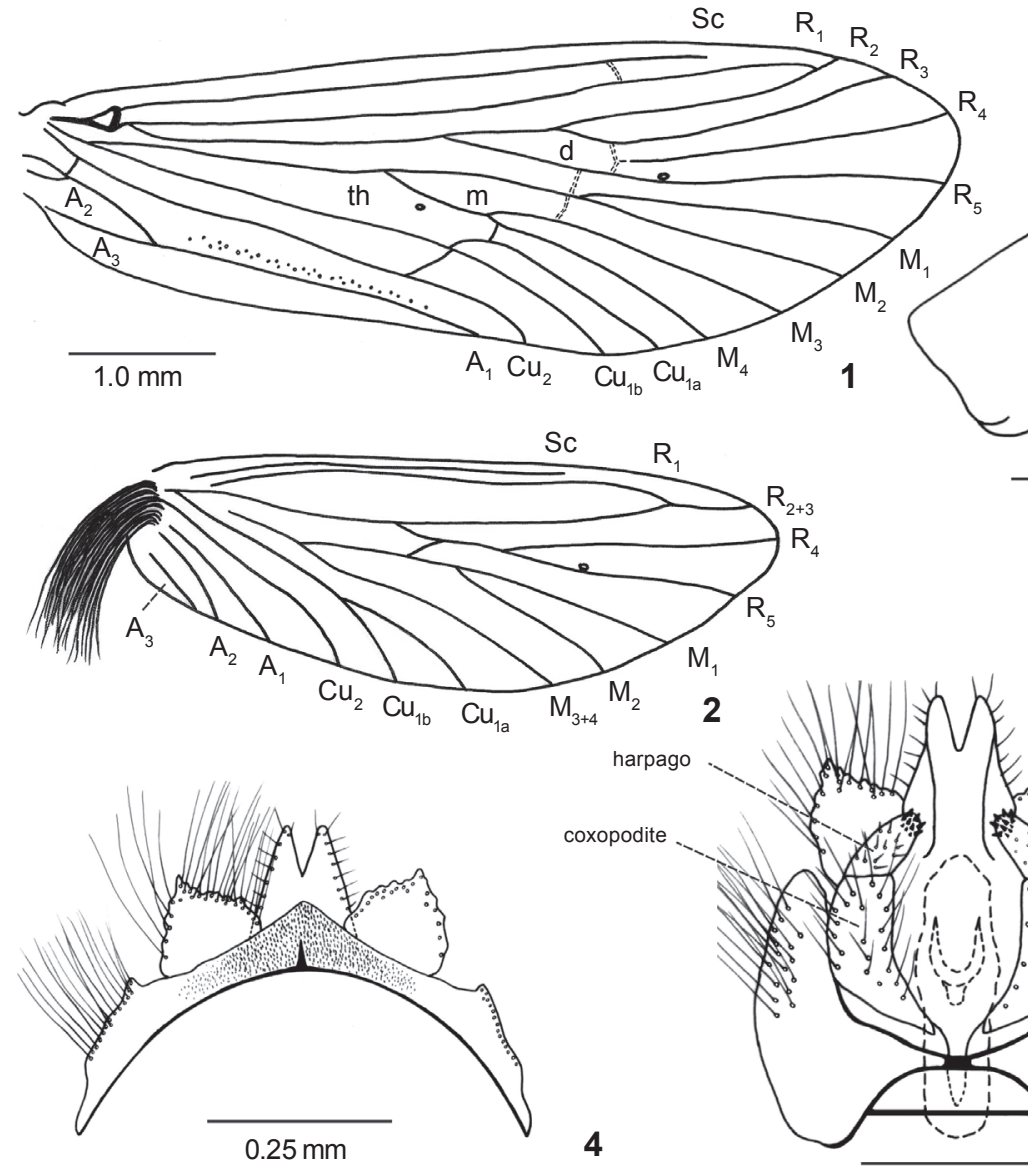

4

Figures 1-6. Phylloicus monneorum sp. nov., male. (1-2) Wings: (1) forewing; (2) hindwing. (d) Discoidal cell, (m) medial cell, (th) thyridial cell. (3-6) Genitalia: (3) lateral view; (4) dorsal view; (5) ventral view; (6) phallus, lateral view. 


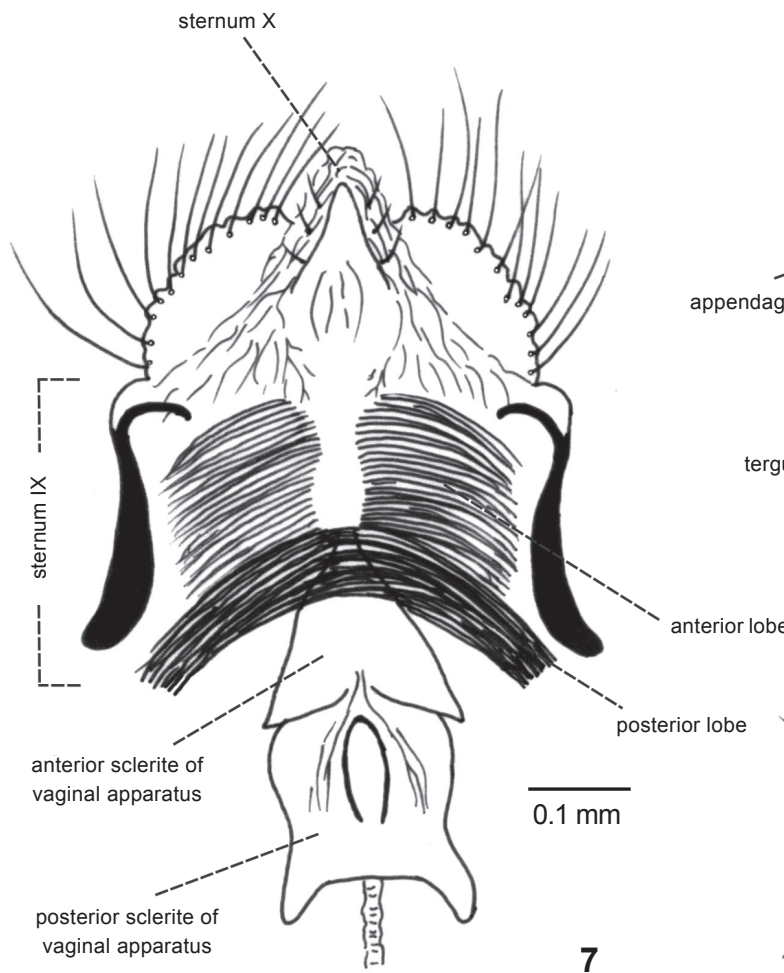

7

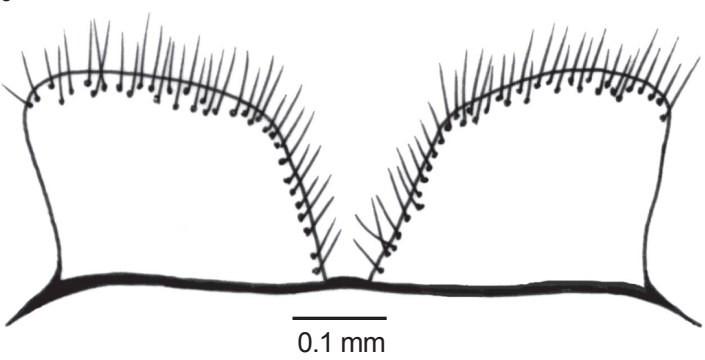

Figures 7-9. Phylloicus monneorum sp. nov., female: (7) sterna IX, X and vaginal apparatus, ventral view; (8) terga IX and X, dorsal view; (9) sternum IX, ventral view.

terior sclerite almost quadrate, with basolateral projections (Fig. 7).

Holotype male: BrazIL, Rio de Janeiro: Itatiaia (Parque Nacional do Itatiaia, Rio Campo Belo tributary in the track to Lago Azul, 22 27'8.38”S, 44³6'40.99”W, 790 m), 08.II.2009, M.A. Monné \& M.L. Monné leg. (DZRJ 2157). Paratypes: BrazIL, Rio de Janeiro: Itatiaia (same data as holotype), 1 male (DZRJ 2158) and 1 female (DZRJ 2159); (Parque Nacional do Itatiaia, track Cachoeira Véu da Noiva to Abrigo Rebouças, $22^{\circ} 25^{\prime} 46.21^{\prime \prime}$, $\left.44^{\circ} 37^{\prime} 9.74^{\prime \prime} \mathrm{W}, 1250 \mathrm{~m}\right), 01-04 . X .2009$, M.A. Monné \& M.L. Monné leg., 1 male (DZRJ 2160); same locality and data, 1 male (DZRJ 2161); same locality and data, 1 male (MZSP).

Etimology. This species is named in honour of Dr. Miguel Angel Monné Barrios and Dr. Marcela Laura Monné Freire, who have collected the type specimens.

Remarks. This species is the smallest known Phylloicus, with forewing lenght ranging from 6.5 to $7.0 \mathrm{~mm}$. In the diagnosis of Phylloicus, Prather (2003) defined the forewing lenght of the genus between 7.0 and $18.5 \mathrm{~mm}$. Phylloicus monneorum sp. nov. is unique within the genus due to the easily recognizable short, flattened preanal appendages (Figs 3 and 5). P. adamsae Prather, 2003 and P. bertioga Prather, 2003 also have short preanal appendages (less than 2/3 lenght of tergum X). Nevertheless, in P. monneorum sp. nov. it is flattened, subtriangular, and possesses irregular margins. In the other two species, the preanal appendages are cylindrical, rounded at apex and the margins have no reentrances. Besides that, the new species can be distinguished by the deeply V-shaped notched tergum X (Fig. 4), whereas in P. adamsae and P. bertioga it is shallowly notched.

\section{ACKNOWLEDGEMENTS}

We thank the Instituto Brasileiro do Meio Ambiente e dos Recursos Naturais Renováveis (IBAMA) and Parque Nacional do Itatiaia for issuing collecting permits (IBAMA 16928-1). This study was partially funded by CNPq, FAPERJ, and CAPES.

\section{LITERATURE CITED}

Flint JR, O.S.; R.W. Holzenthal \& S.C. HarRis. 1999. Catalog of the Neotropical Caddisflies (Insecta: Trichoptera). Colombus, Ohio Biological Survey, IV+239p.

Holzenthal, R.W.; R.J. BlahniK; A.P. Prather \& K.M. KJer. 2007. Order Trichoptera Kirby, 1813 (Insecta), Caddisflies, p. 639-698. In: Z.Q. Zhang and W.A. Shear (Ed.). Linnaeus Tercentenary: Progress in Invertebrate Taxonomy. Zootaxa 1668: 1-766.

Müller, F. 1880. Sobre as Casas Construidas pelas Larvas de Insectos Trichopteros da Província de Santa Catharina. Archivos do Museu Nacional do Rio de Janeiro 3: 99-134. 
Paprocki, H.; R.W. Holzenthal \& R.J. Blahnik. 2004. Checklist of the Trichoptera (Insecta) of Brazil I. Biota Neotropica 4 (1): $1-22$.

Prather, A.L. 2003. Revision of the Neotropical caddisfly genus
Phylloicus (Trichoptera: Calamoceratidae). Zootaxa 275: 1214.

Prather, A.L. 2004. Revision of the Neotropical caddisfly genus Banyallarga (Trichoptera: Calamoceratidae). Zootaxa 435: 1-76.

Submitted: 01.IX.2009; Accepted: 25.II.2010.

Editorial responsibility: Gabriel L.F. Mejdalani 